\title{
HUBUNGAN ADVERSITY QUOTIENT DENGAN CAREER ADAPTABILITY PADA KOAS ANGKATAN 2015 FKG "X" DI RSGM
}

\author{
Yoga Hardianto ${ }^{1)}$, Rizka Bella Sucihayati ${ }^{2)}$ \\ Fakultas Psikologi Universitas Jenderal Achmad Yani, Cimahi \\ ${ }^{1)}$ yogahardianto@hotmail.com, ${ }^{2)}$ rizkabella04@gmail.com
}

\begin{abstract}
This study originated from the lack of research linking adversity quotient with career adaptability. One study found that there was a positive correlation between adversity quotient and career adaptability. The purpose of this research is to know empirically the correlation between adversity quotient with career adaptability in the Coas class of 2015 FKG " $X$ " at RSGM. This research is a quantitative research with correlational research and deductive approach. The number of samples is 65 people and using probability sampling technique is total population sampling. The measuring instrument used is the Adversity Quotient Questionnaire compiled by the researcher based on Paul Stoltz's (2000) theory with the reliability test result is 0.885 and the validity test result is 0.400-0.667 and career adaptability measurements using the Career Adapt-Ability Scale developed by Savickas et. al (2012) with the result of the reliability test is 0.955 and the result of the validity test is 0.404-0.906. Based on the results of hypothesis testing using the Spearman's rho correlation matrix method, there is a significant positive relationship between Adversity Quotient and Career Adaptability in the moderate category $(r=0.580)$. This means that the higher the Adversity Quotient possessed by Koas, the higher the Career Adaptability. As for suggestion for RSGM is to pay more attention to Coas belonging to Campers and Quitters, and also to those who have low Career Adaptability levels.
\end{abstract}

Keywords: Adversity Quotient, Career Adaptability.

ABSTRAK: Penelitian ini berawal dari sedikitnya penelitian yang menghubungkan adversity quotient dengan career adaptability. Salah satu penelitian menemukan bahwa terdapat hubungan positif antara adversity quotient dengan career adaptability. Tujuan dari penelitian ini adalah untuk mengetahui secara empiris hubungan adversity quotient dengan career adaptability pada Koas Angkatan 2015 FKG "X" di RSGM. Penelitian ini merupakan penelitian kuantitatif dengan jenis penelitian correlational research dan pendekatan deduktif. Jumlah sampel sebanyak 65 orang dan menggunakan teknik sampel probability sampling yaitu total population sampling. Alat ukur yang digunakan adalah instrumen Adversity Quotient yang disusun oleh peneliti berdasarkan teori Paul Stoltz (2000) dengan hasil uji reliabilitas 0,885 dan hasil uji validitas 0,400-0,679 dan pengukuran career adaptability menggunakan Career Adapt-Ability Scale yang dikembangkan oleh Savickas et. al (2012) dengan hasil uji reliabilitas 0,955 dan hasil uji validitas 0,404-0,906. Berdasarkan hasil dari pengujian hipotesis dengan menggunakan metode correlation matrix spearman's rho terdapat hubungan positif yang signifikan antara Adversity Quotient dengan Career Adaptability dengan kategori sedang $(r=0,580)$ Artinya, semakin tinggi Adversity Quotient yang dimiliki oleh Koas maka semakin tinggi pula Career Adaptability-nya. Adapun saran untuk RSGM untuk lebih memperhatikan Koas yang tergolong Campers dan Quitters, juga yang memiliki tingkat Career Adaptability yang rendah.

Kata Kunci: Adversity Quotient, Career Adaptability. 


\section{PENDAHULUAN}

Dalam menghadapi era Masyarakat Ekonomi ASEAN (MEA), tingkat persaingan untuk mampu berkarier atau bekerja sangatlah ketat. Persaingan untuk mendapatkan pekerjaan yang sesuai dengan keahlian bukan hanya dengan orang-orang dari Indonesia saja, melainkan harus mampu bersaing juga dengan para orang-orang luar negeri. Namun, di sisi lain hal ini sesungguhnya dapat menjadi kesempatan bagi para calon pekerja untuk terus berupaya mendorong diri meningkatkan keterampilan dan pengetahuan yang dimiliki sehingga menjadi individu-individu yang mampu bersaing dalam era MEA.

Dengan meningkatnya persaingan dalam mendapatkan pekerjaan, para freshgraduate dituntut untuk dapat mengembangkan kemampuan beradaptasi dalam mengatasi tantangan dan transisi kerja yang akan terus berlanjut dalam perkembangan karier mereka (Hou et al., 2012). Terlebih di dalam era MEA, para pekerja mungkin akan menghadapi beberapa perbedaan budaya, agama, dan bahasa. Bagi mereka yang tidak mampu untuk mengembangkan keterampilan dan pengetahuan juga kemampuan untuk berdaptasi mungkin akan mengalami kesulitan untuk mendapatkan pekerjaan (cnnindonesia.com, 2015).

ECC UGM melakukan polling di website www.ecc.ft.ugm.ac.id (dalam careernews.id, 2013) untuk mengetahui lama waktu adaptasi pekerja baru pada semua aspek pekerjaan. Polling tersebut diikuti oleh 219 responden, $77 \%$ diantaranya menyatakan bahwa mereka mampu beradaptasi dalam waktu kurang dari 6 bulan. Sementara itu $21 \%$ responden lainnya perlu waktu 6-12 bulan dan hanya 2\% responden yang perlu waktu lebih dari setahun untuk beradaptasi dengan lingkungan kerjanya yang baru. Hal ini menunjukkan bahwa para calon tenaga kerja di Indonesia akan mampu untuk bersaing di dalam pekerjaannya, karena mereka mampu untuk beradaptasi dalam waktu yang relatif singkat.
Kemampuan untuk beradaptasi dengan dunia kerja mengacu pada Career Adaptability (Savickas, 1997). Teori konstruk karier mengungkapkan bahwa kemampuan adaptasi merupakan faktor penting yang memengaruhi keberhasilan individu di lingkungan pekerjaan. Kemampuan ini terlihat dari perilaku individu dalam merencanakan tindakan, mengeksplorasi situasi lingkungan, dan membuat keputusan atas informasi yang telah diperolehnya mengenai suatu karier (Savickas, 2013).

Perkembangan konsep Career Adaptability berawal dari empat segmen dalam Life-Span \& Life-Space Theory yang dikemukakan oleh Donald Super pada tahun 1981 yaitu individual differences, development, self dan context (Savickas, 1997). Keempat hal ini merupakan perspektif tentang penyesuaian dalam berbagai peran kehidupan. Menurut Savickas (1997) kemampuan adaptasi merupakan konstruk yang sesuai untuk menjembatani keempat segmen tersebut menggeser konsep Career Maturity atau kematangan karier menurut Super tahun 1955.

Menurut Savickas (1997), pada saat ini kemampuan untuk beradaptasi lebih penting dalam mengembangkan karier seseorang. Career Adaptability adalah kesiapan individu untuk menguasai situasi atau perubahan tidak terduga yang mungkin terjadi dalam pekerjaan atau kondisi kerjanya. Career Adaptability (Savickas, 1997) dibentuk oleh empat dimensi yaitu Career Concern, Career Control, Career Curiousity dan Career Confidence. Perkembangan konsep ini tidak hanya secara konseptual melainkan juga secara operasional, karena Savickas et al.(2012) telah membuat instrumen khusus untuk mengukur Career Adaptability.

Berdasarkan review mengenai Career Adaptability yang dilakukan oleh Johnston (2005), variabel career adaptability telah diteliti dan memiliki hubungan yang positif dengan konstruk yang terkait dengan pengejaran tujuan dan konstruk-konstruk yang menghasilkan penyesuaian diri dan strategi coping yang 
positif. Beberapa konstruk tersebut adalah motivation (Poyaud et al., 2012), promotion regulatory focus (Van Vianen et al., 2012), hope and optimism (Buyukgoze-Kavas, 2014), Tenacious goal pursuit and flexible goal adjustment (Tolentino et al.,2013), dan Adversity Quotient\& Environmental Variables (Tian \& Fan, 2014).

Penelitian yang menghubungkan career adaptability dengan adversity quotient nampaknya masih sangat sedikit dan memiliki hasil penelitian yang bertolak belakang, yaitu penelitian yang dilakukan di China oleh Tian \& Fan (2014), dan yang dilakukan di Indonesia oleh Annida, N. et al. (2018). Kedua penelitian tersebut menghubungkan adversity quotient dengan career adaptability.

Tian \& Fan (2014) melakukan penelitian mengenai hubungan adversity quotient dengan career adaptability. Menurut Tian \& Fan (2014) Adversity Quotient adalah personal factor yang berhubungan positif dengan Career Adaptability. Tian \& Fan (2014) menemukan bahwa individu harus mampu beradaptasi dengan kesulitan-kesulitan yang dihadapinya agar terhindar dari stress dan mampu menyesuaikan diri di lingkungan kerjanya (Tian \& Fan, 2014).

Literature review menunjukkan bahwa konsep career adaptability dapat diukur melalui pengukuran terhadap kemampuan individu untuk mengatasi kesulitan atau adversity quotient. Namun, hal ini bertolak belakang dengan penelitian yang dilakukan oleh Annida et al. (2018) yang mencoba menguji hubungan antara adversity quotient dan career adaptability.

Annida et al. (2018) tidak menemukan bahwa terdapat hubungan antara adversity quotient dengan career adaptability. Menurutnya, meskipun tingkat adversity quotient dari individu berada dalam kategori sedang (campers) tidak menutup kemungkinan bahwa mereka memiliki career adaptability yang tinggi. Meskipun tidak ditemukan adanya hubungan antara adversity quotient dengan career adaptability, tetapi Annida et al. (2018) menemukan adanya hubungan antara dimensi reach dan endurance dengan career adaptability.

Konsep Adversity Quotient dibentuk berdasarkan tiga konsep ilmu pengetahuan yaitu, psikologi kognitif, neuropsikologi dan neuroimunologi (Stoltz, 2000). Adversity Quotient digunakan untuk mengukur respon individu terhadap kesulitan, dan untuk memprediksi individu mana yang mampu mengatasi kesulitan dan mana yang tidak. Adversity Quotient juga dapat digunakan untuk memahami apakah individu mampu memenuhi potensi dan mencapai tujuannya. Selain itu, Adversity Quotient juga dapat digunakan untuk memprediksi individu yang akan menyerah di tengah jalan dan yang akan bertahan sampai akhir untuk tujuan mereka (Stoltz, 2000).

Penelitian mengenai Adversity Quotient telah dilakukan pada berbagai macam setting, seperti pada guru, karyawan rumah sakit, manajer, psikolog, pengusaha, agen asuransi, karyawan perusahaan nonprofit, siswa dan lainnya (Phoolka, 2012). Penelitian-penelitian tersebut telah membuktikan bahwa adversity quotient mampu memperbaiki performa kerja, gaya kepemimpinan, resiliensi, promosi, optimisme, dan respon pada perubahan (Phoolka, 2012).

Stoltz (2000) mengatakan bahwa setiap individu memiliki respon yang berbeda dalam merespon perubahan. Individu dengan tingkat adversity quotient yang rendah cenderung menolak perubahan, biasanya mereka menghindar dan secara aktif menjauhi perubahan. Namun, individu dengan tingkat adversity quotient yang tinggi akan menyambut perubahan dengan baik. Mereka memahami bahwa perubahan adalah kenyataan yang tidak akan dapat dihindari. Mereka yakin dengan adanya perubahan, akan mendorong mereka untuk berkembang (Stoltz, 2000).

Career adaptability dapat diukur menggunakan konsep adversity quotient, dimana ketika adversity quotient tinggi maka career adaptability pun tinggi. Meskipun penelitian yang menghubungkan adversity quotient dengan career adaptability masih sangat sedikit, dan hanya satu penelitian yang menemukan bahwa 
adanya hubungan antara kedua variabel tersebut yaitu penelitian yang dilakukan oleh Tian \& Fan (2014).

Hal ini merupakan bagian dari literature review sebelumya, dimana peneliti menemukan adanya gap penelitian secara teoritis. Gap yang dimaksud adalah peneliti menemukan dua penelitian yang menghubungkan adversity quotient dengan career adaptability, tetapi kedua penelitian tersebut menemukan hasil yang berbeda. Selain adanya gap penelitian secara teoritis, jumlah penelitian yang menghubungkan kedua variabel masih sangat sedikit juga membuat peneliti tertarik untuk melihat secara empiris hubungan antara Adversity Quotient dengan Career Adaptability.

Dengan memiliki kemampuan untuk mengatasi kesulitan, individu akan lebih mungkin untuk mampu beradaptasi dengan lingkungan pekerjaan yang baru. Menurut Tian \& Fan (2014) individu yang memiliki tingkat adversity quotient yang tinggi akan mampu melihat kesulitan-kesulitan dalam masa transisi school-to-work sebagai suatu tantangan untuk lebih mengembangkan pengetahuan dan kemampuan untuk beradaptasi dengan lingkungan pekerjaannya.

Hal yang sama ditemukan pada Koas Angkatan 2015 di RSGM FKG "X" adalah para Koas telah menetapkan tujuan karier dan rencana-rencana untuk mencapai tujuan tersebut. Mereka juga merasa yakin akan mampu mencapai tujuan dan akan mampu untuk beradaptasi dengan tujuan karier yang telah ditentukan. Mereka juga sudah mulai mengumpulkan informasiinformasi yang terkait dengan karier yang dikehendakinya. Keyakinan ini diperkuat karena para Koas merasa bahwa ketika dihadapkan dengan kesulitan-kesulitan dalam menyelesaikan requirement di RSGM FKG "X", mereka mampu untuk bertahan dan berhasil mengatasinya. Mereka juga mampu belajar dari kesalahan-kesalahan yang telah diperbuatnya, sehingga mereka menganggap bahwa hal tersebut tidak akan terulang lagi. Namun, terkadang ketika menghadapi kesulitan mereka menjadi tidak fokus dan merasa tidak tenang dalam melakukan aktivitas lain. Hal ini membuat waktu penyelesaian kesulitan menjadi lebih lama, karena mereka memerlukan waktu untuk menenangkan diri terlebih dahulu.

Pada literature review sebelumnya, penelitian yang menghubungkan adversity quotient dengan career adaptability baru sedikit dan memiliki hasil penelitian yang berbeda. Maka dalam penelitian ini, peneliti tertarik untuk menguji adakah hubungan adversity quotient dengan career adaptability pada koas angkatan 2015 di RSGM FKG "X".

Menurut Savickas (1997) konsep Career Adaptability mendukung seseorang untuk mengembangkan karier dalam berbagai situasi pada usia anak-anak, remaja maupun dewasa. Selain iu, Career Adaptability berhubungan kuat dengan kesejahteraan individu secara umum maupun dalam konteks profesional pekerjaan.

Menurut Savickas (1997) Career Adaptability mengacu pada kesiapan individu untuk meyelesaikan tugas yang terprediksi dan berpartisipasi dalam peran pekerjaan, serta mampu menguasai situaasi yang tak terduga yang mungkin terjadi karena perubahan dalam pekerjaan atau kondisi kerjanya. Selanjutnya menurut Savickas (2012) Career Adaptability memungkinkan individu siap mengatasi tugas perkembangan, transisi kerja dan trauma pekerjaan.

Serupa dengan definisi yang telah diuraikan sebelumnya, Savickas dan Porfeli (2012) mendefinisikan Career Adaptability sebagai kekuatan atau kemampuan regulasi diri untuk memecahkan masalah yang tidak biasa, kompleks, dan tidak jelas dalam tugas perkembangan, transisi pekerjaan atau trauma kerja. Dari definisi diatas, dapat ditarik kesimpulan bahwa Career Adaptability merupakan kesiapan individu untuk menyelesaikan dan mengatasi perubahan-perubahan yang mungkin terjadi dalam pekerjaan ataupun dari kondisi kerjanya.

Savickas et al (2012) merumuskan empat dimensi Career Adaptability yang digunakan individu untuk mengelola tugas, transisi, dan trauma dalam membangun karier. Empat dimensi tersebut adalah 
Career Concern, Career Control, Career Curiousity, dan Career Confidence.

Career Concern berfokus pada pertimbangan kesempatan atau harapan dalam hidup dan perasaan optimis (Savickas et al., 2009). Kemudian Savickas (2012) mengungkapkan bahwa Career Concern menyadarkan individu untuk mengembangkan karier, menghadapi transisi kerja, dan perencanaan jangka pendek atau jangka panjang.

Career Control adalah cara individu meregulasi diri untuk menyesuaikan dengan kebutuhan pada stuasi yang berbeda, tapi juga dapat memengaruhi dan mengontrol lingkungan (Savickas et al., 2009). Career Control diindikasikan melalui perilaku disiplin dan mampu bertanggungjawab atas pilihan karier.

Career Curiousity adalah perilaku aktif seseorang untuk mencari tahu informasi dan cara mengembagkan karier untuk meningkatkan peluang sosial (Savickas et al., 2009). Dimensi ini ditunjukkan dalam beberapa perilaku seperti mencoba hal-hal baru, mengambil resiko, mencari informasi, dan perasaan ingin tahu.

Career Confidence adalah kemampuan individu untuk berpedoman pada pendapat dan tujuan sendiri untuk memecahkan masalah ketika menghadapi hambatan dan rintangan (Savickas et al., 2012). Koen et al. (2010) menyatakan bahwa career confidence sebagai rasa kepercayaan diri pada keberhasilan dalam melakukan kegiatan yang dibutuhkan untuk mencapai karier yang dikehendakinya.

Stoltz (1997) mengatakan Adversity Quotient merupakan kapasitas individu dalam mengatasi kesulitan dan hambatan dalam hidupnya yang menunjukkan seberapa baik ia bertahan dan kemampuannya untuk mengatasi kesulitan tersebut.

Menurut Stoltz (2000), AQ adalah kemampuan seseorang dalam mengatasi kesulitan dan hambatan dalam hidupnya. AQ mampu memprediksi bagaimana reaksi individu dalam menghadapi situasi sulit. AQ juga dapat digunakan untuk membantu individu memperkuat kemampuan dan ketekunan mereka dalam menghadapi tantangan hidup sehari-hari, sambil tetap berpegang pada prinsip-prinsip dan impianimpian mereka tanpa memperdulikan apa yang terjadi.

Stoltz (2000) mengungkapkan bahwa Adversity Quotient (AQ) secara keseluruhan terbentuk dari 4 dimensi yaitu Control, Origin \& Ownership, Reach, dan Endurance yang biasa disingkat dengan $\mathrm{CO}_{2} \mathrm{RE}$

Dimensi Control menandakan seberapa kendali yang individu rasakan dalam menghadapi sebuah peristiwa yang menimbulkan kesulitan. Kata kunci dari dimensi ini adalah merasakan. Kendali yang sebenarnya dalam suatu situasi sebenarnya hampir tidak mungkin untuk diukur maka dari itu kendali yang dirasakan jauh lebih penting. Kendali mempengaruhi bagaimana seseorang merespon dan menangani kesulitan.

Dimensi Origin berfokus pada bagaimana individu dapat mengidentifikasi darimana hambatan tersebut berasal. Dimensi ini berhubungan dengan rasa bersalah. Rasa bersalah memiliki 2 fungsi, yang pertama adalah untuk membantu individu untuk belajar. Dengan menyalahkan diri, maka individu akan cenderung merenungkan, belajar, dan menyesuaikan perilaku agar tidak melakukan kesalahan yang sama. Fungsi kedua, rasa bersalah memunculkan penyesalan yang dapat membantu individu untuk meneliti batin dan mempertimbangkan hal-hal yang menyebabkan permasalahan.

Ownership adalah bagaimana seseorang memiliki perasaan bertanggung jawab atas kesulitan yang terjadi. Dalam AQ, dimensi Ownership menekankan pada pentingnya meningkatkan rasa bertanggung jawab sebagai salah satu cara untuk memperluas kendali. Hal ini dapat membantu individu dalam pemberdayaan dan juga motivasi dalam mengambil tindakan.

Dimensi Reach menilai seberapa baik individu mampu membatasi pengaruh dari suatu kesulitan di dalam kehidupannya. Sebagai contoh, bagaimana ia mampu membatasi permasalahannya pada satu 
aspek tertentu saja dimana permasalahan tersebut terjadi, atau apakah individu tersebut membiarkan permasalahan tersebut mempengaruhi area lain dari kehidupannya.

\section{Dimensi}

Endurance

mempertanyakan dua hal yaitu, Berapa lamakah suatu kesulitan akan berlangsung dan berapa lama penyebab dari kesulitan tersebut akan berlangsung. Dimensi Endurance adalah keyakinan dari individu bahwa penyebab dari suatu masalah yang terjadi hanya bersifat sementara. Begitu pula dengan permasalahan yang sedang terjadi hanya bersifat sementara dan akan segera selesai sehingga individu mampu untuk bertahan dalam waktu lama dalam menghadapi permasalahan tersebut.

\section{METODE PENELITIAN}

Metode penelitian yang digunakan adalah penelitian kuantitatif dengan menggunakan kuesioner yang telah dirancang oleh peneliti. Jenis penelitian yang digunakan dalam penelitian ini adalah correlational research. Penelitian ini memiliki kegunaan untuk mencari hubungan antara dua variabel atau lebih yang dilakukan dengan menghitung korelasi antar variabel yang akan dicari hubungannya, sehingga diperoleh arah dan kuatnya hubungan antara dua variabel atau lebih yang akan diteliti (Sugiyono, 2017). Peneliti menggunakan pendekatan deduktif. Penelitian ini menggunakan teknik Total Population Sampling, yaitu teknik pengambilan sampel dengan menjadikan seluruh yang ada dalam populasi sebagai sampel penelitian yaitu sebanyak 65 orang.

Alat ukur yang digunakan adalah Inventori Adversity Quotient yang disusun oleh peneliti berdasarkan teori Stoltz (2000) dengan jumlah item 20 dan hasil uji reliabilitas 0,885 dan hasil uji validitas pernyataan antara 0,400-0,679. Kemudian, untuk pengukuran Career Adaptability menggunakan Career Adapt-Ability Scale yang dikembangkan oleh Savickas et. Al (2012) dengan jumlah item 24 dan hasil uji reliabilitas 0,955 dan hasil uji validitas pernyataan antara 0,404-0,906. Analisis data yang digunakan dalam penelitian ini menggunakan perangkat lunak JASP versi 0.8.5.1 dengan uji Correlation Matrix Spearman.

\section{HASIL DAN PEMBAHASAN}

Hubungan adversity quotient dengan career adaptability pada partisipan, didapatkan $(p)$ nilai signifikansi $<0.001$ (one-tailed). Hal ini menunjukkan bahwa hasil penelitian mengenai hubungan kedua variabel adalah terdapat hubungan positif yang signifikan, dengan demikian dapat disimpulkan bahwa terdapat hubungan positif antara adversity quotient dengan career adaptability pada Koas angkatan 2015 FKG "X" di RSGM. Berdasarkan perhitungan statistik, nilai koefisien korelasi atau $r$ antara adversity quotient dengan career adaptability yang diperoleh sebesar 0,580 . Hal ini menunjukkan bahwa adanya korelasi positif yang tergolong sedang antara kedua variabel.

Tabel 1. Hasil tabel silang antara adversity quotient dengan career adaptability

\begin{tabular}{cccc}
\hline Adversity & \multicolumn{3}{c}{ Career Adaptability } \\
\cline { 2 - 4 } Quotient & Tinggi & Sedang & Rendah \\
\hline \multirow{2}{*}{ Tinggi } & 18 & 12 & 1 \\
& $(58,1 \%)$ & $(38,7 \%)$ & $(3,2 \%)$ \\
Sedang & 6 & 7 & 6 \\
& $(31,6 \%)$ & $(36,8 \%)$ & $(31,6 \%)$ \\
Rendah & 0 & 4 & 11 \\
& $(0 \%)$ & $(26,7 \%)$ & $(73,3 \%)$ \\
\hline
\end{tabular}

Berdasarkan tabel 1 dapat dilihat tabulasi silang antara adversity quotient dengan career adaptability pada Koas angkatan 2015 FKG "X" di RSGM. Koas yang memiliki adversity quotient yang tinggi dan career adaptability yang tinggi berjumlah 18 orang $(58,1 \%)$, career adaptability sedang berjumlah 12 orang $(38,7 \%)$, dan career adaptability rendah berjumlah 1 orang $(3,2 \%)$. Kemudian Koas yang memiliki adversity quotient yang sedang dengan career adaptability yang tinggi berjumlah 6 orang $(31,6 \%)$, career adaptability sedang bejumlah 7 orang $(36,8 \%)$ dan career adaptability rendah berjumlah 6 orang $(31,6 \%)$. Lalu koas yang memiliki adversity quotient yang rendah 
dengan career adaptability yang tinggi berjumlah 0 orang $(0 \%)$, career adaptability sedang berjumlah 4 orang $(26,7 \%)$ dan career adaptability rendah berjumlah 11 orang $(73,3 \%)$.

Berdasarkan hasil korelasi antara empat dimensi adversity quotient didapatkan nilai signifikansi ( $p$ )yang sama yaitu $<0.001$ pada seluruh dimensi adversity quotient yaitu Control, Origin \& Ownership, Reach dan Endurance.Hal ini menunjukkan adanya hubungan positif yang signifikan antara masing-masing dimensi adversity quotient dengan career adaptability. Dari keempat dimensi adversity quotient, origin \& ownership memperoleh nilai koefisien korelasi paling tinggi diantara dimensi yang lainnya, yaitu $r=0,533$ yang artinya terdapat hubungan positif dan tergolong kategori sedang antara dimensi origin \& ownership dan career adaptability. Artinya semakin tinggi origin \& ownership Koas maka akan semakin tinggi juga career adaptability nya.

Dimensi kedua dengan nilai koefisien korelasi tertinggi adalah dimensi control, yaitu $r=0,490$ yang artinya terdapat hubungan positif dan tergolong sedang antara dimensi control dengan career adaptability. Hal ini menunjukkan bahwa semakin tinggi control Koas ketika menghadapi kesulitan maka semakin tinggi pula tingkat career adaptability nya.

Dimensi ketiga yaitu, endurance dengan nilai koefisien korelasi yaitu $r=0,445$ yang artinya terdapat hubungan positif dengan kategori sedang antara dimensi endurance denga career adaptability. Hal ini menunjukkan bahwa semakin tinggi endurance maka semakin tinggi pula career adaptability.

Dimensi yang terakhir adalah reach dengan nilai koefisien korelasi yaitu $r=0,392$ yang artinya terdapat hubungan positif dengan kategori rendah antara reach dengan career adaptability. Hal ini menunjukkan semakin tinggi dimensi reach maka semakin tinggi pula tingkat career adaptability Koas.

Tabel 2. Kategorisasi variabel adversity quotient

\begin{tabular}{cccc}
\hline Tipe & Rentang & Frekuensi & Persentase \\
\hline Climbers & $\geq 72$ & 31 & 47,7 \\
Campers & $67-71$ & 19 & 29,2 \\
Quitters & $\leq 66$ & 15 & 23,1 \\
& & 65 & 100 \\
\hline
\end{tabular}

Berdasarkan hasil kategorisasi dapat diketahui bahwa Koas yang memiliki tingkat adversity quotient yang tinggi berjumlah 31 orang $(47,7 \%), 19$ orang $(29,2 \%)$ memiliki tingkat adversity quotient yang sedang dan 15 orang $(23,1 \%)$ memiliki tingkat adversity quotient yang rendah.

Tabel 3. Kategorisasi career adaptability

\begin{tabular}{cccc}
\hline \multicolumn{4}{c}{ Kategorisasi Career Adaptability } \\
$(\mathrm{M}=101,523$ & $\mathrm{SD}=9,04)$ \\
\hline Kategorisasi & Rentang & Frekuensi & Persentase \\
\hline Tinggi & $\geq 106$ & 24 & 36,9 \\
Sedang & $98-105$ & 23 & 35,4 \\
Rendah & $\leq 97$ & 18 & 27,7 \\
Total & & 65 & 100 \\
\hline
\end{tabular}

Dapat diketahui bahwa Koas yang termasuk memiliki tingkat career adapatability yang tinggi berjumlah 24 orang $(36,9 \%), 23$ orang $(35,4 \%)$ termasuk pada kategori career adaptability sedang, dan 18 orang $(27,7 \%)$ termasuk pada kategori career adaptability rendah.

Tabel 4. Hasil Uji Korelasi

\begin{tabular}{llcc}
\hline & & $\begin{array}{c}\text { TOTAL } \\
\text { AQ }\end{array}$ & $\begin{array}{c}\text { TOTAL } \\
\text { CA }\end{array}$ \\
\hline TOTAL & $\begin{array}{l}\text { Spearman's } \\
\text { rho }\end{array}$ & - & \\
AQ & $p$-value & - & \\
& Spearman's & $0.580 * * *$ & - \\
TOTAL & rho & $<.001$ & - \\
CA & $p$-value & $<.001$ & - \\
\hline
\end{tabular}

Note . all tests one-tailed, for positive correlation

$* p<.05, * * p<.01, * * * p<.001$, one-tailed

Berdasarkan hasil yang diperoleh setelah dilakukan uji korelasi pada adversity quotient dengan career adaptability terlihat bahwa kedua variabel memiliki hubungan positif yang signifikan dengan kategori korelasi yang tergolong sedang $(r=0,580$, 
$p<.001)$. Dapat disimpulkan bahwa pada penelitian ini $\mathrm{H}_{0}$ ditolak dan $\mathrm{H}_{\mathrm{a}}$ diterima yang artinya terdapat hubungan positif antara adversity quotient dengan career adaptability. Hal ini menunjukkan bahwa semakin tinggi adversity quotient maka semakin tinggi pula career adaptability.

Pada hasil penelitian ini, hubungan antara adversity quotient dengan career adaptability tergolong pada kategori yang sedang. Artinya hal ini menunjukkan perilaku Koas saat mengerjakan tugas dan menghadapi kesulitan, mereka masih menunjukan inisiatif untuk segera mengatasi kesulitan yang dihadapinya, dengan harapan mereka masih berada pada kondisi yang aman yaitu masih bisa menyelesaikan tugas tersebut meskipun mendapatkan penilaian yang tidak terlalu bagus. Mereka seringkali mengalami patah semangat dan berkecil hati ketika menghadapi kesulitan. Para Koas juga seringkali menunda tugas-tugas yang dianggap sulit.Ketika mereka merasa sudah mampu untuk mengatasi kesulitannya barulah mereka mulai mengerjakan tugas yang dianggap sulit. Mereka cenderung menyelesaikan segala sesuatu yang dirasa perlu untuk dilakukan saja, dan tidak pernah mengembangkan keterampilan yang lain. Ketika diberikan tugas yang lebih sulit, mereka merasa dirinya tidak mumpuni untuk menyelesaikan tugas tersebut. Sehingga mereka merasa hanya perlu menyelesaikannya saja, tidak untuk menjadi lebih menguasai cara-cara penyelesaian tugas tersebut. Hal ini membuat para Koas menjadi kurang yakin bahwa dirinya akan mampu mencapai tujuan karier yang dikehendakinya. Mereka juga tidak berusaha untuk mencari tahu cara-cara penyelesaian suatu tugas atau kesulitan dengan cara-cara yang lain, mereka masih mengikuti cara-cara yang biasanya, hal ini karena mereka merasa cukup dengan hal-hal yang telah ia ketahui. Mereka merasa belum mampu untuk beradaptasi dengan masa transisi ke dunia kerja atau dengan perubahan-perubahan pada kariernya nanti, karena mereka masih membutuhkan bantuan dari oranglain untuk menyelesaikan kesulitan-kesulitan yang telah dihadapinya.
Menurut Tian \& Fan (2014)
adveristy quotient merupakan faktor personal yang memprediksi kinerja, resilien, ketekunan dan juga respon pada perubahan. Dalam menghadapi masa transisi dari school-to-work, para Koas akan dihadapkan dengan beberapa perubahan dan juga kesulitan. Ketika ia memiliki adversity quotient yang tinggi, ketika menghadapi masa transisi tersebut ia akan memiliki keyakinan bahwa segala kesulitan yang akan dihadapinya pasti dapat teratasi. Hal ini tentunya dengan melakukan kegiatankegiatan yang mengasah kemampuannya dalam mengatasi kesulitan tersebut. Seperti ia mampu untuk tetap tenang ketika menghadapi kesulitan, sehingga mampu berfikir positif dan menemukan cara penyelesaian kesulitan tersebut. Selain itu, ia juga akan memiliki rasa ingin terus belajar dari kesalahan yang telah ia perbuat. Hal ini tentunya akan sangat membantu dalam upaya beradaptasi dengan kariernya nanti.

Kemudian, berdasarkan hasil penelitian bahwa dimesi Control, Origin \& Ownership dan Endurance memiliki hubungan positif yang signifikan dengan Career Adaptability. Hal ini menunjukkan bahwa keyakinan Koas bahwa segala kesulitan akan dapat teratasi, kemampuan untuk bertanggung jawab dan memiliki rasa optimis dan percaya diri berhubungan dengan kemampuannya untuk beradaptasi dengan dunia kerjanya nanti. Sedangkan untuk dimensi Reach memiliki koefisien korelasi yang tergolong rendah dengan career adaptability. Hal ini menunjukan bahwa kemampuan Koas untuk membatasi pengaruh dari kesulitan atau masalah yang sedang dihadapinya tidak begitu berhubungan dengan kemampuannya untuk beradaptasi dengan dunia kerjanya nanti.

Berdasarkan hasil penelitian, hubungan antara adversity quotient dengan career adaptability tergolong pada korelasi yang sedang. Hal ini menunjukkan bahwa tidak hanya adversity quotient yang memiliki hubungan dengan career adaptability, tetapi ada faktor lain seperti motivasi (Poyaud et al, 2012), dukungan sosial dan work environment (Tian \& Fan, 2014). 
Motivasi memiliki hubungan positif yang signifikan dengan career adaptability, motivasi menunjukkan bahwa individu akan mampu benar-benar terlibat pada masa kini, masa depan dan memiliki kemampuan untuk melakukan segala sesuatunya dengan rasa percaya diri (Poyaud et al, 2012). Menurutnya individu yang memiliki motivasi, ciri-cirinya sangat mirip dengan adaptive individuals. Dimana ia menjadi peduli dengan masa depan, bertindak untuk mempersiapkan masa depannya, menunjukan rasa ingin tahu dengan mengeksplorasi kemungkinan-kemungkinan yang akan terjadi di masa depan dan mengembangkan rasa percaya diri untuk mencapai tujuannya (Poyaud et al, 2012).

Hirschi (2009) menemukan bahwa dukungan sosial merupakan salah satu prediktor atas career adaptability pada mahasiswa. Terutama dukungan dari keluarga memainkan peran yang penting dalam perkembangan karier individu. Ia menyimpulkan bahwa dukungan keluarga seperti kehangatan, dukungan, dan keterikatan berdampak pada konstruksi karier mahasiswa. Maka dari itu, dukungan sosial adalah hal yang penting untuk meningkatkan kemampuan adaptasi karier, terutama dukungan dari keluarga.

Selain motivasi dan dukungan sosial, faktor lain yang berhubungan dengan career adaptability adalah environmental variables(Tian \& Fan, 2014). Menurutnya, lingkungan kerja atau lingkungan pendidikan yang positif akan membantu individu untuk mengembangkan kemampuan personal dan profesionalnya. Hal ini adah untuk mencegah adanya ketidaksesuaian dari lingkungan pendidkan dengan lingkungan kerja yang sesungguhnya. Maka dari itu, lembaga pendidikan harus mampu menciptakan lingkungan belajar yang mendukung dan positif sehingga akan meningkatkan career adaptability individu.

Koas RSGM FKG "X" angkatan 2015 sebagian besar temasuk pada tipe Climbers (Lihat Tabel 5). Ciri-ciri dari para climbers adalah mereka memiliki semangat yang tinggi untuk terus belajar dan berjuang untuk bisa mendapatkan hal-hal terbaik di hidup mereka, mereka benar-benar memahami tujuannya, yakin bahwa segala hal dapat terlaksana, selalu mencari cara baru untuk tumbuh, dan menjadikan kesulitan ataupun perubahan sebagai kesempatan untuk berkembang. Ketika dihadapkan dengan tugas yang sulit, mereka mampu untuk mengatasi dan menyelesaikan tugas tersebut walaupun harus melewati banyak tantangan. Mereka juga mampu mengidentifikasi sumber kesulitan itu berasal dan belajar dari kesalahan yang telah diperbuat. Lalu ketika mereka membuat kesalahan, mereka bertanggung jawab dan berusaha untuk memperbaiki hal tersebut. Kesulitan atau masalah yang sedang dihadapi, tidak membuat mereka menjadi patah semangat dan kewalahan. Hal ini justru membuat mereka berinisiatif untuk segera menyelesaikan kesulitan tersebut dengan keyakinan bahwa kesulitan dan masalah itu adalah hal yang sementara.

Koas FKG "X" angkatan 2015 di RSGM sebagian besar memiliki tingkat Career Adaptability yang tinggi. Menurut Savickas dan Porfeli (2012) individu dengan career adaptability tinggi adalah individu yang telah mempersiapkan diri dengan baik untuk menghadapi tantangan dan kesulitan dalam dunia kerja. Mereka juga memiliki kemauan untuk memulai proses mencapai integrasi dirinya dengan lingkungan yang akan menjadi motivasi untuk memulai tindakan dalam mencapai kariernya. Dalam mempersiapkan kariernya, para Koas sudah mulai menetapkan rencana dan juga mempelajari berbagai hal yang berkaitan dengan tujuan kariernya. Mereka juga sudah mulai mengeksplorasi lingkungan sekitarnya untukmencari peluang dalam mengembangkan dirinya, sehingga mereka merasa yakin bahwa mereka akan mampu beradaptasi dengan dunia kariernya nanti.

Terdapat temuan yang menarik pada penelitian ini yaitu, terdapat 1 orang yang tergolong Climbers namun memiliki tingkat Career Adaptability yang rendah. Ketika dihadapkan dengan kesulitan, ia mampu untuk mengatasinya dan juga mampu bertanggungjawab atas kesalahan yang telah ia perbuat. Ia juga memiliki keyakinan bahwa segala kesulitan akan dapat diatasi. 
Namun, dalam upaya mempersiapkan kariernya ia belum menetapkan tujuan dan belum berinisiatif untuk mengeksplorasi mengenai peluang-peluang kariernya.

\section{SIMPULAN DAN SARAN}

\section{Simpulan}

Penelitian ini memperoleh hasil terdapat hubungan positif yang signifikan antara Adversity Quotient dengan Career Adaptability yang tergolong sedang. Artinya, semakin tinggi adversity quotient dari Koas maka semakin tinggi pula career adaptability-nya.

Dimensi Control, Origin \& Ownersip, Endurance memiliki hubungan positif yang signifikan dengan Career Adaptability. Hal ini menunjukkan bahwa keyakinan untuk mampu mengendalikan kesulitan, belajar dari kesalahan dan memiliki inisiatif untuk segera mengatasi kesulitan akan membantu Koas untuk lebih mampu beradaptasi dengan kesulitan dan tantangan di dalam kariernya.

Koas angkatan 2015 FKG "X" di RSGM yang termasuk kategori Climbers berjumlah 31 orang $(47,7 \%)$, Campers berjumlah 19 orang $(29,2 \%)$, dan Quitters berjumlah 15 orang $(23,1 \%)$.

Koas angkatan 2015 FKG "X" di RSGM yang termasuk kategori Career Adaptability tinggi berjumlah 24 orang $(36,9 \%), \quad$ Career Adaptability sedang berjumlah 23 orang $(35,4 \%)$, dan Career Adaptability rendahberjumlah 18 orang $(27,7 \%)$.

\section{Saran}

Kepada peneliti yang akan melakukan penelitian yang sama agar lebih detail membahas mengenai masing-masing dimensi dari Adversity Quotient. Kemudian untuk lebih mempelajari faktor-faktor lain yang mungkin lebih berhubungan dengan Career Adaptability selain Adversity Quotient. Seperti, motivasi, dukungan sosial dan environmental variables dan lebih memperhatikan data demografi dari partisipan penelitian, seperti jenis kelamin, usia, tingkat pendidikan, dan juga budaya.

Kepada Koas diharapkan untuk memiliki keyakinan bahwa segala kesulitan akan mampu teratasi dengan melakukan berbagai usaha, jangan mudah menyerah ketika menghadapi kesulitan dan tetap berpikir positif sehingga akan mudah untuk menemukan alternatif penyelesaian masalah. Dengan hal ini, career adaptability pun akan meningkat.

Kepada pihak RSGM untuk lebih memperhatikan Koas yang tergolong Campers dan Quitters, mereka akan mampu mengatasi kesulitan jika mendapatkan dorongan dari orang lain. Selain itu, lebih perhatikan Koas yang memiliki tingkat Career Adaptability yang rendah. Untuk meningkatkan Career Adaptability dapat diusahakan dengan mengadakan workshop mengenai karier sebagai Dokter Gigi.

\section{DAFTAR PUSTAKA}

Annida, N.S., Kurniawan, Y., \& Nur, O. H. (2018). The Relationship Between Adversity Quotient and Career Adaptability of Internship Nursing Students. JNC, Vol. 1 No.1. Faculty of Nursing Padjadjaran University.

Buyukgoze-Kavas, A. (2014). Validation of the Career Adapt-Abilities ScaleTurkish form and its relation to hope and optimism. Australian Journal of Career Development, 23, 125-132. doi: $10.1177 / 1038416214531931$

Career Issue. (2013). 77\% Bisa adaptasi kurang dari enam bulan. http://careernews.id/issues/view/2166 -77-Bisa-Adaptasi-Kurang-dariEnam-Bulan (Diakses pada 3 Mei 2018, 08:58 PM)

Dancey, Christine P. \& Reidy, J. (2007). Statistic Without Maths for Psychology (Fourth Edition). England. Pearson Education Limited. University of East London.

Dokter Gigi, Jangan Khawatir tidak kerja. Diakses pada 13 Mei 2018, dari 
https://dental.id/dokter-gigi-jangankhawatir-tidak-kerja/

Dokter Gigi dan MEA. Diakses pada 13 Mei 2018, darihttps://dental.id/doktergigi-dan-mea/

Dokter di Indonesia Siap Hadapi MEA.Diakses pada 13 Mei 2018, dari https://lifestyle.kompas.com/ $\mathrm{read} / 2017 / 02 / 08 / 203152923 /$ dokter.d i.indonesia.siap.hadapi.mea

Ebenehi, A.S., Rashid, A.M., \& Bakar, A.R. (2016). Predictors of Career Adaptability skill among higher education students in Nigeria. International Journal for Research in Vocational Education and Training. Vol. 3. No. 3. 212-229. doi: 10.13152/IJRVET.3.3.3

Herr, E.L., \& Cramer, S.H. (1984). Career Guidance and Counseling Through the Life Span. Amerika Serikat: Little, Brown\&Company.

Hirschi, A. (2009). Career adaptability development in adolescence: Multiple predictors and effect on sense of power and life satisfaction. Journal of Vocational Behavior, 74, 145-155. Doi: 10.1016/j.jvb.2009. 01.002

Hou, Z., Leung, S.A., Li, X., Li, X., \& Xu, H. (2012). Career adapt-abilities scale-China form: Construction and initial validation. 80, 689-691.

Johnston, C.S. (2005). A systematic review of the Career Adaptability Literature and future Outlook. Publication Jurnal of Career Assessment.

Koen, J., Klehe, U. C., Van Vianen, A. E., Zikic, J., \& Nauta, A. (2010). Jobsearch strategies and reemployment quality: The impact of career adaptability. Journal of Vocational Behavior, 77, 126-139.

Koen, J., Klehe, U., \& Vianen, A.E.M. Van. (2012). Training career adaptability to facilitate a successful school-towork transition. Journal of Vocational Behavior, 81(3), 395-408.

Patton, W. \& McMahon, M. (1999). A New Relationship: Career Development and Systems Theory. Canada: Brooks/Cole Publishing Company
Pemerintah Diminta Waspadai Penganggurang Bertambah akibat MEA. Diakses pada 13 Mei 2018, dari https://www.cnnindonesia.com /ekonomi/20151127113026-7894450/pemerintah-diminta-waspadaipengangguran-bertambah-akibat-mea

Phoolka, S, \& Kaur, N. (2012). Adversity Quotient: A New Paradigm to Explore. International Journal of Contemporary Business Studies. Vol. 3, No. 4. 67-78.

Pouyaud, J., Vignoli, E., Dosnon, O., \& Lallemand, N. (2012). Career adaptabilities scale-France form: Psychometric properties and relationships to anxiety and motivation. Journal of Vocational Behavior, 80, 692-697. doi:10.1016/j.jvb.2012.01.021

Rottinghaus, P. J, Day, S. X. Borgen, F. H. (2005). The Career Futures Inventory: A measure of CareerRelated Adaptability and Optimism. Journal of Career Assessment, 13, 324. doi: 10.1177/1069072704270271

Savickas, M.L. (1997). Career Adaptability: An Integrative Construct for LifeSpan, Life-space theory. The Career Development Quarterly. 45, 247-259.

Savickas, M. L. (2009). Life-design International Research Group: Career Adaptability Project Meeting. Meeting Report, Berlin July 19, Humboldt Universität.

Savickas, M.L., \& Porfeli, E.J. (2012). Career adapt-abilities scale: Construction, reliability, and measurement equivalence across 13 countries. Journal of Vocational Behavior, 80, 661-673.

Savickas, M. L. (2013). Career construction theory and practice. Career development and counseling: Putting theory and research to work (2nd ed.) Hoboken, NJ: Wiley.

Stoltz, P.G. (1997). The Most Important Factor in Achieving Success; Adversity Quotient; Turning Obstacles into Opportunities. Amerika Serikat: John Wiley \& Sons, Inc. 
Stoltz, P.G. (2000). Faktor Paling Penting dalam Meraih Sukses: Adversity Quotient: Mengubah Hambatan Menjadi Peluang. (Hermaya, T., terj.). Jakarta: Grasindo. (Karya Asli terbit 1997).

Sugiyono. (2017). Metode Penelitian Kuantitatif, Kualitatif, Dan $R \& D$. Bandung: Alfabeta.

Susetyo, B. (2014). Statistika Untuk Analisis Data Penelitian (Dilengkapi Cara Perhitungan dengan SPSS dan MS. Office Excel). Bandung: PT. Refika Aditama.

Sullivan, S. E., \& Arthur, M. B. (2006). The evolution of the boundaryless career concept: Examining physical and psychological mobility. Journal of Vocational Behavior, 69, 19-29.

Tian, Yan, \& Fan, Xiuzhen. (2014). Adversity Quotients, Environmental Variabels and Career Adaptability in Student Nurse. Journal of Vocational Behavior, 85, 251-257.

Turner, R. H. (1960). Sponsored and contest mobility and the school system. American Sociological Review, 25, 855-867.

Van Vianen, A. E. M., Klehe, U.-C., Koen, J., \& Dries, N. (2012). Career adaptabilities scale-Netherlands form: Psychometric properties and relationships to ability, personality, and regulatory focus. Journal of Vocational Behavior, 80, 716-724. doi:10.1016/j.jvb.2012.01.002

Zacher, H. (2014). Career adaptability predicts subjective career success above and beyond personality traits and core self-evaluations. Journal of Vocational Behavior, 84(1), 21-30. doi:10.1016/J.Jvb.2013.10.002 